\title{
JIHAD DALAM PERSPEKTIF MUHAMMAD FETHULLAH GULEN
}

\author{
\begin{tabular}{l|l}
$\begin{array}{l}\text { Husni Fithriyawan } \\
\text { husni.hoeve85@gmail.com }\end{array}$ & $\begin{array}{l}\text { SMP YPI Darussalam 1 Cerme, } \\
\text { Jl. Pasar Cerme Lor No. 3, Kec. } \\
\text { Cerme, Kab. Gresik }\end{array}$
\end{tabular}
}

Abstract: According to Fethullah Gulen, Jihad in a muslim spiritual life is a process to know closer one's God. There are two kinds of jihad in his opinion; major jihad which is a jihad for oneself and minor jihad, which is directed toward others. Jihad toward oneself is considered a major jihad because it is directed to fight against one's destructive ego as well as negative thought. Such things could deny a muslim to attain the ultimate perfection. By subduing oneself negative aspects, he or she will discover his/her true identity and finally discover and love his/her God.by doing so, he or she will get spiritual happiness. In contrast, minor jihad is an active fulfilment of a Muslim toward his or her religion. Major jihad influences dearly to minor jihad. Both jihads should work hand in hand. While major jihad has spiritual nature, minor jihad is physical. A good muslim will always perform jihad so that he or will have a balance of spiritual and physical life. Key words: Jihad, Muhammad Fethullah Gulen.

Abstrak: Jihad dalam pandangan Fethullah Gulen merupakan sebuah proses dalam kehidupan seorang muslim agar lebih dekat dan mengenal Allah. Menurutnya, ada dua kategori jihad, yakni jihad besar yang merupakan jihad terhadap diri sendiri dan jihad kecil yang merupakan jihad terhadap orang lain. Jihad terhadap diri sendiri masuk dalam kategori jihad besar karena memerangi ego, emosi dan pikiran yang negatif dalam diri manusia sebagai upaya mengatasi hambatan antara diri sendiri dan jati dirinya, mengenali jiwa, dan akhirnya mengenali Tuhan, mencintai Tuhan, dan berbahagia secara spiritual. Sedangkan jihad kecil merupakan pemenuhan aktif seseorang terhadap perintah dan tugas dalam Islam, proses untuk membuat orang lain bisa mencapai jati dirinya didasarkan pada mengatasi hambatan antara manusia dan keimanan sehingga mereka dapat memilih secara bebas untuk beriman atau tidak beriman. Jihad yang pertama kali harus dilakukan adalah jihad besar, karena ia memiliki pengaruh yang signifikan bagi jihad kecil. Jihad dalam Islam yang menekankan pada harmonisasi antara jihad besar yang bersifat batiniah dan jihad kecil yang bersifat lahiriah, maka orang beriman yang selalu berjihad, baik jihad kecil maupun besar, akan memiliki keseimbangan fisik dan spiritual yang sangat bagus.

Kata Kunci: Jihad, jihad besar, jihad kecil, Muhammad Fethullah Gulen. 


\section{Pendahuluan}

Banyak orang yang menggunakan istilah jihad dengan cara yang tidak tepat. Jihad merupakan salah satu aspek ajaran Islam yang paling sering disalahpahami dan disalahgunakan. Di satu sisi, beberapa muslim ekstremis mengeksploitasi konsep jihad untuk tujuan politik mereka sendiri. Di sisi lain, banyak non muslim salah memahami jihad untuk mendiskreditkan Islam dan kaum muslimin. ${ }^{1}$

Sudah menjadi pengetahuan umum bahwa Islam merupakan agama yang mengusung prinsip musyawarah dan dialog simpatik. Oleh karena itulah, penyelesaian berbagai masalah kontemporer yang melibatkan kaum muslimin di dunia harus dilakukan melalui upaya saling memahami dan saling menghormati. Sebaliknya kekerasan atas nama agama justru sering menimbulkan kerusakan yang lebih buruk dan kontraproduktif terhadap tujuan pemecahan masalah.

Dewasa ini jihad seringkali dipahami tidak sebagaimana mestinya. Kondisi ini dipicu oleh beberapa sebab, salah satunya interpretasi yang salah terhadap makna jihad, baik yang dipahami oleh beberapa Kaum Muslim atau non-Muslim, bahwa jihad dalam Islam merupakan situasi yang tidak terkendali, irasional, dan konotasinya perang total. ${ }^{2}$ Banyak Kaum Muslim yang terpengaruh pandangan seperti itu atau ada juga yang berjihad tetapi tidak sesuai dengan etika jihad yang diajarkan oleh Rasulullah saw dan para sahabatnya. Pada akhirnya, konsep jihad yang komprehensif sebagaimana yang diletakkan oleh para ulama pun menjadi salah di mata mereka. Akibatnya, Islam dituduh sebagai agama yang ditegakkan dan dikembangkan dengan kekerasan. ${ }^{3}$

Konsep jihad bukanlah ideologi terorisme. Terorisme dan jihad tidak bisa dipandang secara hitam-putih. Keduanya harus dipahami dengan pengamatan yang jeli, karena pemahaman jihad yang bersifat superfisial dan dangkal akan mengakibatkan radikalisme dan ekstremisme. ${ }^{4}$

Jihad merupakan salah satu tema yang sering diperbincangkan pada awal abad ke-21 M, khususnya setelah terjadinya tragedi 11 September

\footnotetext{
${ }^{1}$ Irwan Masduqi, Ketika Non Muslim Membaca al-Qur'an,(Yogyakarta: Bunyan, 2013), 140.

2 Rif at Husnul Ma'afi dan Muttaqin , Konsep Jihad dalam Perspektif Islam", Kalimah, Volume 11, Nomor 1, Maret 2013, 134.

${ }^{3}$ Ibid., 135.

${ }^{4}$ Irwan Masduqi, Ketika Non Muslim Membaca al-Qur'an, 215.
} 
2001 yang menghubungkan adanya aksi terorisme dan konsep jihad di dalam Islam. Hal ini pun berlanjut hingga saat ini dengan masih adanya aktifitas gerakan ISIS yang menghalalkan berbagai aktifitas pembunuhan, pemerkosaan, penjarahan, dan lain sebagainya dengan alasan jihad sesuai pemahaman mereka. Dengan kejadian ini, Islam diidentikkan oleh orangorang non-muslim sebagai terorisme. Di sisi lain, terdapat usaha yang meluruskan pemahaman tentang Islam, salah satunya dilakukan oleh seorang cendekiawan muslim Turki, Muhammad Fethullah Gulen yang dikenal dengan gerakan hizmet-nya, yang mencoba mereinterpretasikan konsep jihad dalam Islam agar lebih fleksibel dan kontekstual.

Gulen adalah seorang tokoh besar Islam kontemporer berkebangsaan Turki yang beraliran Sunnî-Hanafî dengan pengaruh utama pemikiran Saîd Nursî (1878-1960). Perhatian utamanya adalah pemikiran Islam ortodoks, konservatisme Islam, pendidikan, dialog antaragama dan budaya, dan menjadikan tasawuf sebagai spirit sentralnya. Spirit inilah yang menjadi motor utama gerakan dakwah Gulen ke berbagai penjuru dunia melalui gerakan yang akrab disebut hizmet. Seleksi sejarah mengantarkannya menjadi tokoh paling populer setelah dianugerahi sebagai tokoh intelektual nomor wahid di dunia, menang telak atas 99 tokoh lainnya dari 100 tokoh intelektual, dengan perolehan lebih dari 500.000 suara masyarakat global menurut versi survei majalah The Guardian, 23 Juni 2008. 5

Fethullah Gulen membagi jihad menjadi dua, yakni jihad besar dan jihad kecil. Dalam pandangannya, jihad besar menekankan pada sebuah usaha untuk mencapai jati diri seseorang melalui olah ruhani dan pendidikan, sedangkan jihad kecil lebih menekankan pada usaha untuk menjadikan orang lain mengenal dirinya.

Berdasarkan latar belakang di atas, maka artikel ini membahas tentang jihad menurut M. Fethullah Gulen.

\section{Biografi Muhammad Fethullah Gulen}

Muhammad Fethullah Gulen lahir pada 27 April 1941 di Korucuk, sebuah desa kecil di Anatolia yang berpenduduk hanya sekitar 60-70 kepala keluarga. Desa ini termasuk distrik Hasankale (Pasinler) dalam wilayah provinsi Erzurum. Leluhur Gulen berasal dari distrik Ahlat

\footnotetext{
${ }^{5}$ Sokhi Huda, "Pemikiran dan Praksis Dakwah Sufistik M. Fethullah Gülen", Islamica, Volume 11, Nomor 2, Maret 2017, 312.
} 
(Khalat) dan termasuk dalam wilayah provinsi Bitlis yang terletak di kaki gunung. Pada zaman dulu, keturunan Rasulullah saw ada yang berhijrah ke Bitlis untuk menyelamatkan diri dari kezaliman penguasa Bani Umayyah dan Bani Abbasiyyah. Di tempat itu mereka menjadi pembimbing spiritual bagi masyarakat, sehingga semangat keislaman merasuk ke dalam jiwa suku-suku Turki yang tinggal di kawasan ini. ${ }^{6}$

Fethullah Gulen lahir di keluarga yang sangat agamis dan sarat akan semangat keislaman yang kental, dari pasangan suami istri yang sangat taat. Ayah Gulen bernama Ramiz Gulen yang terkenal sebagai pribadi yang berpengetahuan tinggi, taat, cerdas, murah hati dan dermawan. Adapun Ibu Gulen bernama Rafiah Hanim adalah sosok wanita yang memiliki perangai yang sopan dan penyuka kebaikan. Dia adalah seorang guru al-Qur'an bagi kaum wanita di desanya. Kakeknya yang bernama Syamil Agha adalah pribadi yang mencerminkan sikap sungguh-sungguh dan teguh dalam beragama. Sedangkan nenek Gulen dari pihak ayah bernama Munise Hanim. Munise dikenal sebagai seorang tokoh wanita yang sangat taat beragama dan ketaatannya itu tercermin dari kehidupannya sehari-hari. Nenek Gulen dari pihak ibu bernama Khadijah Hanim, dia berasal dari kalangan bangsawan yang terkenal dengan kelembutan dan kesantunannya. ${ }^{7}$

Jauh sebelum Muhammad Fethullah Gulen dilahirkan, rumah yang ditempatinya sering dikunjungi oleh banyak ulama yang tinggal di kawasan tersebut. Ramiz Gulen ayahnya memang diketahui sangat mencintai para ulama dan gemar bersilaturahmi dengan mereka, hingga hampir tiap hari ada saja ulama yang dijamu di rumahnya. Pada saat itu, seorang ulama sufi bernama Muhammed Lutfi yang berasal dari Alvar, diakui oleh Fethullah Gulen telah memberi pengaruh besar pada dirinya.

Pendidikan Muhammad Fethullah Gulen dimulai di rumah. Fethullah Gulen belajar membaca al-Qur'an dari ibundanya. Di tengah malam, ibunya bangun untuk mengajarinya bacaan al-Qur'an dan memberikan beberapa nasehat kepadanya. Sehingga ketika usia Fethullah Gulen baru menginjak empat tahun, dia telah mampu mengkhatamkan al-Qur'an hanya dalam waktu satu bulan. ${ }^{8}$ Kemampuan bahasa Arab dan

\footnotetext{
${ }^{6}$ Muhammad Fethullah Gulen, "Siapakah Fethullah Gulen?" dalam www.fgulen.com diakses 30 Desember 2016.

${ }^{7}$ lbid.

${ }^{8}$ lbid.
} 
Persia diperoleh Fethullah Gulen dari ayahnya, Ramiz Gulen, yang diketahui sangat giat menelaah berbagai buku dan istiqamah membaca alQur'an di mana pun dia berada. Ayah Fethullah Gulen, sangat mencintai Rasulullah saw dan senang sekali membaca buku tentang sejarah beliau. Di dalam rumahnya, siapa pun dapat menemukan tumpukan buku-buku sîrah nabawiyyah yang lusuh karena terlalu sering dibaca. Dari sana, salah satu nilai terpenting yang ditanamkan Ramiz Gulen kepada putranya, Fethullah Gulen, adalah kecintaan kepada Rasulullah saw dan para sahabat. ${ }^{9}$ Pendidikan yang telah dimulai Muhammad Fethullah Gulen dari rumahnya sendiri ini kemudian berlanjut dalam lembaga pendidikan formal yang terdapat di kota Erzurum. Di kota ini dia mempelajari ilmuilmu keislaman dari beberapa orang ulama besar, di antaranya adalah Osman Bektasi, seorang ulama paling terkemuka di masanya. Dari gurunya ini, Gulen mempelajari ilmu nahwu, balâghah, fikih, ushûl alfiqh, dan teologi. Pada masa-masa inilah, Fethullah Gulen mulai mengenal Said Nursi melalui gerakan yang dilakukan murid-muridnya dan menelaah karya-karyanya, khususnya Risale-i Nur. ${ }^{10}$ Dalam hal spiritual, selepas dididik oleh sang Ayah, Ramiz Gulen, M. Fethullah Gulen melanjutkan untuk berguru pada Muhammad Lutfi Efendi. Fethullah Gulen pernah melontarkan sebuah pernyataan tentang Muhammed Lutfi:

"Saya dapat mengatakan bahwa saya telah berutang banyak kepada beliau atas semua yang telah beliau ajarkan dan membentuk karakter serta kepribadian saya." ${ }^{11}$

Berkat pendidikan yang diterimanya dari gurunya ini, pendidikan spiritual Gulen pun tidak terputus dan terus berlangsung di sepanjang hidupnya secara berdampingan dengan ilmu-ilmu keislaman. Di sekolah formal ini juga, Fethullah Gulen juga rajin membaca serta menelaah berbagai buku ilmu-ilmu umum seperti fisika, kimia, astronomi, dan biologi. Ketekunan itulah yang membuat Fethullah Gulen memiliki wawasan sangat luas dalam ilmu-ilmu tersebut. Di masa-masa ini juga, Fethullah Gulen mulai berkenalan dengan pemikiran beberapa filosof

\footnotetext{
${ }^{9}$ lbid.

${ }^{10}$ Muhammad Fethullah Gulen, "Pendidikan Dasar dan Kepribadian M. Fethullah Gulen" dalam www.fgulen.com diakses 30 Desember 2016.

11 lbid.
} 
Barat melalui berbagai karyanya seperti Albert Camus, Jean Paul Sartre, Herbert Marcuse, dan lainnya. ${ }^{12}$

Setelah Muhammad Fethullah Gulen menginjak usia dua puluh tahun, dia meninggalkan kota kelahirannya, Erzurum yang terletak di ujung timur Turki, menuju kota Edirne yang menjadi gerbang bagi Turki ke dunia barat. Di kota itu, dia menjadi Imam Besar di Masjid Uc Serefeli selama dua tahun. Di sana, dia melewati hari-harinya dengan penuh kezuhudan dan ketekunan. Selama menjadi Imam Besar, Fethullah Gulen nyaris tidak pernah meninggalkan masjid dan hanya keluar jika keadaan memang memaksa. Padahal saat itu, tidak ada tempat khusus di dalam masjid yang dapat menjadi tempat tinggalnya, sehingga beliau pun terpaksa tidur hanya dengan beralaskan kasur tipis tepat di bawah jendela besar yang terdapat di salah satu sudut masjid. ${ }^{13}$

Setelah menjadi Imam Besar di Edirne, tepatnya pada tanggal 11 November 1960, Fethullah Gulen menjalani wajib militer di kota Mamak dan Iskenderun. Wajib militer ini berlaku bagi setiap warga laki-laki Turki yang sudah mencapai usia dewasa. Biasanya, kegiatan ini dilaksanakan selama 15 bulan, khusus bagi lulusan SMA atau belum masuk universitas, dan 6 bulan bagi yang sudah lulus universitas atau sudah bekerja. ${ }^{14}$

Di Kota Mamak, Fethullah Gulen ditempatkan pada unit Talat Aydemir sebagai operator radio selama delapan bulan. Setelah itu, Fethullah Gulen ditempatkan di Iskenderun. Di sana, Fethullah Gulen sering menghabiskan waktu luangnya untuk membaca al-Qur'an dan buku-buku lainnya, bahkan ada seorang komandannya yang menganjurkannya agar Fethullah Gulen membaca buku Barat klasik untuk menambah wawasannya tentang pemikiran di Barat. ${ }^{15}$

Karena kelelahan dalam dinas militer dan menderita penyakit kuning, Fethullah Gulen pernah dirawat di rumah sakit. Setelah sembuh, dia diberi cuti selama 3 bulan untuk istirahat. Dalam masa cuti tersebut, Fethullah Gulen pulang ke kota Erzurum yang telah dia tinggalkan 4 tahun sebelumnya. Di sana, Fethullah Gulen sempat pergi ke Halk Evi (Gedung Rakyat) untuk memberikan sebuah seminar tentang pemikiran

\footnotetext{
${ }^{12}$ lbid.

${ }^{13}$ M. Fethullah Gulen, "Fethullah Hodjaefendi" dalam www.fgulen.com diakses 30 Desember 2016.

${ }^{14}$ M. Fethullah Gulen, "Wajib Militer" dalam www.fgulen.com diakses 30 Desember 2016

${ }^{15} \mathrm{lbid}$.
} 
Mawlana Rumi. Dan ketika Fethullah Gulen telah menyelesaikan dinas militernya, dia kembali lagi ke Edirne dan menjadi Imam Besar Masjid. ${ }^{16}$

Pada tahun 1966, Muhammad Fethullah Gulen berpindah lagi ke Izmir. Fethullah Gulen memulai kiprahnya di kota Izmir dengan menjadi guru di sebuah Pondok Pesantren al-Qur'an Kestane Pazari. Pada saat itulah, dia sering melakukan kunjungan di seluruh kawasan barat Anatolia. Dan ketika memasuki tahun 1970, dimulailah sebuah babak baru dalam hidup Fethullah Gulen yang disebut al-mukayyamat, yaitu ketika dia bernazar untuk membaktikan dirinya di jalan Allah dan kemanusiaan, yang diwujudkan dengan mendidik orang-orang agar taat serta tekun beribadah kepada Allah swt. ${ }^{17}$ Melalui pengajaran yang disampaikannya, Fethullah Gulen berhasil menggugah hati para jamaahnya sekaligus memasukkan nilai-nilai moral yang luhur ke dalam jiwa mereka hingga membuat batin mereka kembali hidup. ${ }^{18}$

Pada tanggal 12 Maret 1971, Fethullah Gulen ditangkap oleh pemerintah Turki dengan tuduhan merencanakan makar dengan cara mengubah landasan sosial-politik yang dianut Turki, mengeksploitasi ketaatan masyarakat Turki terhadap Islam, serta menggalang gerakan bawah tanah untuk mewujudkan niat jahat terhadap pemerintah. Untungnya penahanan ini hanya berlangsung selama enam bulan, karena setelah proses pengadilan dilakukan, semua tuduhan yang diarahkan terhadap Gulen ternyata tidak terbukti sama sekali. ${ }^{19}$ Setelah kembali menduduki jabatannya sebagai Imam, Fethullah Gulen ditugaskan di kota Edremit di provinsi Balikesir, lalu dia dimutasi ke provinsi Manisa, dan kemudian dimutasi lagi ke kota Bornova di provinsi Izmir. Di kota ini, Fethullah Gulen menetap sampai bulan September tahun 1980. Pada tahun-tahun itulah, Fethullah Gulen melakukan perjalanan keliling Turki untuk menyampaikan ceramah ilmiah dengan beragam topik meliputi masalah agama, sosial, filsafat, dan pemikiran. Selain itu, Fethullah Gulen juga mengadakan kuliah-kuliah umum yang ditujukan untuk menjawab berbagai pertanyaan yang disampaikan generasi muda, khususnya dari kalangan alumni perguruan tinggi. Ternyata, jawaban yang disampaikan

\footnotetext{
${ }^{16} \mathrm{lbid}$.

${ }^{17}$ M. Fethullah Gulen, "Fethullah Hodjaefendi"

${ }^{18} \mathrm{lbid}$.

${ }^{19}$ M. Fethullah Gulen, "Edirne, Kirklareli, dan Akhirnya Izmir" dalam www.fgulen.com diakses 30 Desember 2016.
} 
Fethullah Gulen dalam kuliah-kuliah umum tersebut dapat memberi pencerahan bagi banyak kalangan seperti para mahasiswa, guru, pedagang, wiraswastawan, dan berbagai profesi lainnya. Itulah cikal-bakal sebuah gerakan yang disebut dengan Hizmet Movement (pelayanan untuk masyarakat yang bersumber dari pemikiran Fethullah Gulen Hocaefendi) yang melibatkan begitu banyak orang dari berbagai bidang. ${ }^{20}$

Tanpa berharap pamrih dari pihak mana pun dan dengan tetap mematuhi undang-undang serta peraturan yang berlaku di Turki, orangorang yang terlibat dalam gerakan Hizmet Movement ini kemudian mendirikan sekolah-sekolah umum dan sekolah persiapan khusus untuk para pelajar yang akan masuk perguruan tinggi. Tidak lama setelah Uni Soviet runtuh, gerakan ini juga menyebar hampir ke seluruh dunia, khususnya di kawasan Asia Tengah. Ketika banyak muslim lain yang tidak sempat melakukan apa-apa bagi masyarakat karena terjebak dalam debat kusir soal "dâr al-Islâm" dan "dâr al-Harb", Fethullah Gulen dan gerakan yang dicetuskannya menunjukkan hasil nyata yang berguna bagi masyarakat banyak dan menyatakan bahwa Turki adalah "dâr al-Khidmat" (Tempat Pelayanan). Pendapat yang dilontarkan Gulen itu ternyata dibuktikannya sendiri olehnya dengan melakukan pengabdian bukan hanya di Turki, melainkan di pelbagai penjuru dunia. ${ }^{21}$

Dalam gerakan berkhidmat atau Hizmet Movement inilah orangorang yang bekerja untuk masyarakat tanpa mengharap pamrih duniawi berkumpul. Bahkan dengan mengusung semboyan "Cinta dan Sabar", orang-orang yang terlibat dalam gerakan ini tidak pernah mengharapkan kedudukan apa pun. Tidak ada waktu bagi mereka untuk bertengkar, karena mereka sibuk dengan tindakan-tindakan positif dan kerja nyata, tanpa pernah mau membalas keburukan dengan keburukan lainnya. ${ }^{22}$

\section{Pengertian dan Macam Jihad menurut Muhammad Fethullah Gulen}

Muhammad Fethullah Gulen memulai pemaknaan terhadap jihad dengan menguraikannya dari akar katanya dalam bahasa Arab. Dalam hal ini, dia menyatakan: Berasal dari akar kata ja-ha-da, jihad berarti mengerahkan seluruh kekuatan, bergerak menuju tujuan dengan segala

\footnotetext{
${ }^{20} \mathrm{M}$. Fethullah Gulen, "Fethullah Hodjaefendi"

${ }^{21} \mathrm{lbid}$.

${ }^{22} \mathrm{lbid}$.
} 
kekuasaan dan kekuatan, dan melawan setiap kesulitan. Definisi jihad ini lebih dekat dengan pengertian keagamaan. ${ }^{23}$

Fethullah Gulen membagi jihad menjadi dua, yakni jihad besar dan jihad kecil. Dalam pandangannya, jihad besar menekankan pada sebuah usaha untuk mencapai jati diri seseorang melalui olah ruhani dan pendidikan, sedangkan jihad kecil lebih menekankan pada usaha untuk menjadikan orang lain mengenal dirinya. Dalam hal ini, Fethullah menyatakan:

Jihad memperoleh karakteristik khusus dengan munculnya Islam: berjuang di jalan Allah. Pengertian ini biasa kita ingat dewasa ini. Jihad terjadi pada dua lapis: internal dan eksternal. Lapis internal (jihad besar) adalah upaya untuk mencapai jati diri seseorang, lapis eksternal (jihad kecil) adalah proses untuk membuat orang lain bisa mencapai jati dirinya. Yang pertama didasarkan pada mengatasi hambatan antara diri sendiri dan jati dirinya, mengenali jiwa, dan akhirnya mengenali Tuhan, mencintai Tuhan, dan berbahagia secara spiritual. Yang kedua didasarkan pada mengatasi hambatan antara manusia dan keimanan sehingga mereka dapat memilih secara bebas untuk beriman atau tidak beriman. ${ }^{24}$

Menurut Muhammad Fethullah Gulen, jihad adalah tujuan penciptaan dan kewajiban manusia yang paling penting, khususnya bagi kaum muslim. Seandainya yang benar adalah kebalikannya, Allah pasti sudah mengutus para Nabi melakukan tugas ini. Dan ada perbedaan yang sangat jauh antara orang-orang yang tetap enggan dengan tanpa alasan yang benar dan mereka yang terus-menerus terlibat dalam jihad. ${ }^{25}$ Untuk mendukung argumennya, Fethullah Gulen mengutip ayat QS. al-Nisâ’: 95 dan hadis Nabi saw:

Tidaklah sama antara mukmin yang duduk (yang tidak turut berperang) yang tidak mempunyai uzur dengan orang-orang yang berjihad di jalan Allah dengan harta mereka dan jiwanya. Allah melebihkan orang-orang yang berjihad dengan harta dan jiwanya atas orang-orang yang duduk satu derajat. Kepada masing-masing mereka Allah menjanjikan pahala yang baik (surga) dan Allah melebihkan orang-orang yang berjihad atas orang yang duduk dengan pahala yang besar. ${ }^{26}$

\footnotetext{
${ }^{23}$ M. Fethullah Gulen, Toward a Global Civilization of Love and Tolerance, (New Jersey: The Light Inc., 2004), 171.

24 lbid.

${ }^{25}$ Ibid., 171-172.

26 Tim Penyusun, al-Qur'an dan Terjemahnya, (Madinah: Mujamma' al-Malik Fahd li Ţhibâ'ah alMushhaf al-Syarîf, 1418 H.), 136.
} 
Rasulullah saw bersabda:

'Abd Allah ibn Munir bercerita kepada kami: dia mendengar dari Abu alNadr: 'Abd al-Rahman ibn 'Abd Allah ibn Dinar bercerita kepada kami dari Abu Hazim dari Sahl ibn Sa'd al-Sa' idi: Sesungguhnya Rasulullah saw bersabda: "Berjaga satu hari untuk melindungi perbatasan untuk berjuang di jalan Allah adalah lebih baik dari pada dunia dan segala isinya. Tempat kecil yang digunakan untuk menyimpan cambukmu (yang digunakan di jalan Allah) di surga lebih baik dari pada dunia dan segala isinya. Malam atau pagi yang dihabiskan di jalan Allah adalah lebih baik dari pada dunia dan segala isinya". ${ }^{27}$

Jihad kecil dalam pandangan Fethullah Gulen memiliki arti yang lebih luas daripada hanya sekedar perang fisik. Ia juga berarti berbagai aktifitas kebaikan sehari-hari yang diniatkan tulus karena Allah. Dalam hal ini, dia menyatakan:

Jihad kecil tidak berarti hanya sebatas peperangan, yang hanya akan mempersempit pandangan kita. Sebenarnya, jihad kecil memiliki arti dan aplikasi sedemikian luas sehingga kadang-kadang mengucapkan sepatah kata atau diam, mengerutkan kening atau tersenyum, meninggalkan atau mengikuti pertemuan — singkatnya, semua yang dilakukan karena Allahdan mencintai atau marah karena Allah dapat termasuk jihad kecil. Dengan cara ini, semua upaya yang dilakukan untuk mereformasi masyarakat adalah bagian dari jihad, demikian pula setiap usaha yang dilakukan untuk keluarga, kerabat, tetangga, dan wilayah anda. ${ }^{28}$

Perbedaan yang mendasar dari dua jenis jihad di atas, menurut Fethullah Gulen, adalah terletak pada wilayah atau bentuk jihad. Wilayah jihad kecil berada pada tataran fisik, sedangkan jihad besar berada dalam wilayah spiritual. Jihad kecil adalah pemenuhan aktif seseorang terhadap perintah dan tugas dalam Islam, sedangkan jihad besar adalah memerangi ego yang merusak serta emosi dan pikiran yang negatif (seperti kedengkian, kebencian, iri hati, keegoisan, kesombongan, arogansi, dan keangkuhan) dalam diri manusia yang dapat menghalanginya untuk mencapai kesempurnaan. Karena jihad ini sangat sulit dan berat, maka jihad ini disebut jihad besar. Dan kedua jihad ini harus dilakukan secara seimbang agar tidak terjadi ketimpangan dalam diri seseorang. ${ }^{29}$

\footnotetext{
${ }^{27}$ Muhammad ibn Ismâ'îl al-Bukhâriy, al-/âmi' al-Shahîh li al-Bukhâriy, Vol. 10, (Beirut: Dâr al-Fikr, tt.), 19.

${ }^{28} \mathrm{M}$. Fethullah Gulen, Toward a Global Civilization, 172.

${ }^{29} \mathrm{lbid}$.
} 
Tetapi perlu diketahui bahwa jihad yang pertama kali harus dilakukan adalah jihad besar. Karena ia memiliki pengaruh yang signifikan bagi jihad kecil. Dalam hal ini, Fethullah Gulen menyatakan bahwa orangorang yang berhasil dalam jihad besar akan berhasil dalam jihad kecil; mereka yang gagal dalam jihad besar akan gagal dalam jihad kecil. Bahkan jika orang-orang seperti itu memperoleh keberhasilan dalam tingkatan tertentu, mereka tidak dapat memperoleh hasil yang sempurna. ${ }^{30}$

Dalam pandangan Fethullah Gulen, orang-orang yang beriman yang selalu berjihad, baik jihad kecil maupun besar, akan memiliki keseimbangan fisik dan spiritual yang sangat bagus. Mereka akan selalu mendapatkan limpahan kenikmatan dari Allah. Dalam hal ini, mereka diibaratkan dengan sebuah pohon yang bertahan hidup justru dengan berbuah. Karena ketika sebuah pohon berhenti berbuah, maka otomatis dia telah mencapai masa kematiannya. Dalam hal ini, Fethullah Gulen menyatakan:

Orang-orang yang beriman menemukan kedamaian dan vitalitas dalam jihad yang demikian imbang. Mereka menyadari bahwa hanya kematianlah yang akan menghentikan mereka untuk berjihad. Orangorang yang beriman, seperti pohon buah, hanya bisa bertahan hidup selama mereka menghasilkan buah. Memang, ketika pohon berhenti menghasilkan buah, ia mengering dan mati. Perhatikan orang-orang yang pesimis, dan anda akan melihat bahwa mereka tidak akan berjuang lagi atau menjelaskan kebenaran kepada orang lain. Dengan demikian, Allah memotong karunia-Nya kepada mereka, membiarkan ruang batin mereka gelap dan dingin. Tetapi mereka yang berjihad selalu dikelilingi oleh cinta dan antusiasme. Dunia batin mereka cerah, perasaan mereka murni, dan mereka berada di jalan menuju kemakmuran. Setiap perjuangan merangsang pemikiran yang lain, dan dengan demikian suatu lingkaran kebenaran terbentuk. Seperti setiap perbuatan baik menjadi kendaraan untuk suatu perbuatan baik lainnya, orang-orang seperti ini berenang di tengah perbuatan-perbuatan baik. ${ }^{31}$

Dan untuk mendukung argumennya ini, dia mengutip firman Allah QS. al-'Ankabut: 69:

\footnotetext{
${ }^{30}$ Ibid., 173.

${ }^{31}$ lbid., 172.
} 
Dan orang-orang yang berjihad untuk (mencari keridaan) Kami, benarbenar akan Kami tunjukkan kepada mereka jalan-jalan Kami. Dan sesungguhnya Allah benar-benar beserta orang-orang yang berbuat baik. ${ }^{32}$

Menurut Fethullah Gulen, ayat tersebut dapat dipahami bahwa banyak jalan menuju Allah sebanyak makhluk yang ada. Allah memberi petunjuk kepada mereka yang berjuang keras di jalan-Nya menuju keselamatan melalui satu atau lebih dari jalan-jalan tersebut. Allah membuka setiap jalan yang menuju kebaikan dan menutup jalan-jalan menuju kejahatan. Dan pada akhirnya, setiap orang yang menemukan jalan-Nya, jalan yang lurus, akan menemukan jalan tengah (keseimbangan). Jika seseorang mengikuti jalan tengah ini dalam berbagai hal dalam hidupnya seperti marah, jihad dan ibadah maka dia akan dibimbing oleh Allah menuju jalan keselamatan. ${ }^{33}$

Selanjutnya, menurut Fethullah Gulen, jihad merupakan keseimbangan ketundukan internal dan eksternal. Mencapai kesempurnaan spiritual dan membantu orang lain melakukan hal yang sama adalah hal-hal yang paling penting. Mencapai kesempurnaan internal adalah jihad besar; membantu orang lain mencapai itu adalah jihad kecil. Ketika seseorang memisahkan jihad yang satu dari yang lainnya, jihad tidak lagi menjadi jihad. Jika seseorang meninggalkan jihad yang yang kecil, maka dia akan menjadi "lamban" dalam hidupnya; sedangkan jika seseorang meninggalkan jihad yang besar, maka akan menjadikan seseorang berlaku anarki dan tanpa aturan. Jadi, satu-satunya jalan adalah dengan mengikuti ajaran Rasulullah saw. Betapa bahagianya mereka yang mencari cara untuk menyelamatkan orang lain segigih yang mereka lakukan untuk diri mereka sendiri. Dan betapa bahagianya mereka yang selalu ingat untuk menyelamatkan diri sambil menyelamatkan orang lain. ${ }^{34}$

Contoh pelaksanaan jihad, baik kecil maupun besar, yang paling ideal ada pada zaman Rasulullah saw saat masih hidup. Di siang hari, Rasulullah saw dan para Sahabat berjuang seperti singa di medan perang, dan ketika malam tiba, beliau dan para Sahabatnya melenyapkan diri dalam pengabdian kepada Allah melalui ibadah dan zikir (mengingat dan menyeru Allah). Para pejuang yang gagah berani ini menjalani hidup di

\footnotetext{
${ }^{32}$ Tim Penyusun, al-Qur'an dan Terjemahnya, 638.

${ }^{33} \mathrm{M}$. Fethullah Gulen, Toward a Global Civilization, 173.

${ }^{34}$ Ibid., 174.
} 
sudut-sudut yang sepi, mereka menyendiri dalam ibadah mengikuti teladan Nabi saw, manusia hati yang pertama dalam jihad material dan spiritual. Beliau selalu mendorong para Sahabatnya untuk selalu meminta ampunan kepada Allah, dan tentunya, beliau selalu menjadi orang yang pertama untuk melakukannya. ${ }^{35}$ Dalam hal ini, Fethullah Gulen mengutip sebuah hadis riwayat Sayyidah 'Aisyah ra. yang menceritakan bahwa suatu malam Rasulullah saw bertanya: "Aisyah, bolehkah aku menghabiskan malam ini bersama Tuhanku?" (Beliau begitu sopan sampai beliau meminta izin. Beliau adalah orang yang sangat mulia dan halus budibahasanya). 'Aisyah pun menjawab: "Wahai Rasulullah, aku ingin bersamamu, tapi aku lebih menginginkan apa yang Engkau sukai bahkan lebih dari itu." Nabi lalu berwudhu dan mulai shalat. Beliau membacakan, "Sesungguhnya dalam penciptaan langit dan bumi, dan silih bergantinya malam dan siang terdapat tanda-tanda bagi orang-orang yang berakal". (Q.S. Ali Imran: 190). Beliau membacakan ayat ini dan menangis sampai pagi. $^{36}$

Kadang-kadang agar tidak membangunkan istrinya, Nabi saw bangun dan menjalankan ibadah tanpa memberitahu 'Aisyah. Sekali lagi 'Aisyah menyatakan:

Suatu malam ketika aku terbangun, aku tidak menemukan Rasulullah saw.

Ketika aku mulai bangkit dalam gelap, tanganku menyentuh kaki beliau.

Beliau bersujud di atas sajadah dan membaca sesuatu. Aku mendengarkan doa beliau. Beliau berdoa, "Ya Allah, aku berlindung kepada keridhaan$\mathrm{Mu}$ dari murka-Mu. Aku berlindung kepada kemurahan-Mu dari azabMu. Aku berlindung kepada-Mu dari-Mu. Aku belum mampu memujiMu dengan sepenuhnya. Engkau seperti Engkau memuji diri-Mu. ${ }^{\text {37 }}$

Kejadian ini jelas menunjukkan kedalaman batin dan kegigihan jihad dalam diri Nabi saw. Dalam hadis lain, Rasulullah saw menyinggung dua jenis jihad:

Nashr ibn 'Ali al-Jahdhamiy bercerita kepada kami: Bisyr ibn 'Umar bercerita kepada kami: Syu’aib ibn Ruzaiq, Abu Syaibah bercerita kepada kami: 'Atha' al-Khurasaniy bercerita kepada kami dari 'Atha' ibn Abi

\footnotetext{
${ }^{35} \mathrm{Ibid} ., 173$.

${ }^{36}$ Ismâ'îl ibn 'Umar ibn Kathîr, Tafsîr al-Qur'ân al-'Azîm, Vol. 2, (Madînah: Dâr Tayyibah li al-Nashr wa al-Tauzî́, 1999), 189.

${ }^{37}$ Muslim ibn al-Hajjâj, al-/âmi' al-Shahîh li al-Muslim, Vol. 3, (Beirut: Dâr al-Fikr, tt.), 36.; Muhammad ibn 'Isâ al-Tirmidziy, al-Jâmi' al-Kabîr li al-Tirmidziy, Vol. 5, (Beirut: Dâr al-Gharb al-Islâmiy, 1996), $474-475$.
} 
Rabah dari ibn 'Abbas ra.: beliau berkata: Saya mendengar Rasulullah saw bersabda: "Ada dua macam mata yang tidak akan pernah melihat api neraka: Mata para prajurit yang bertindak sebagai penjaga di medan perang, dan mata mereka yang menangis karena takut kepada Allah". ${ }^{38}$

Menurut Fethullah Gulen, jihad orang-orang yang tidak tidur karena bertindak sebagai penjaga di saat-saat yang paling berbahaya adalah jihad material. Mata mereka tidak akan tunduk pada api neraka. Adapun orang-orang yang melakukan jihad spiritual dan besar dan menangis karena takut kepada Allah, mereka juga tidak akan melihat siksaan neraka. $^{39}$

Tujuan jihad sebenarnya bukan untuk jihad itu sendiri, melainkan demi terciptanya perdamaian dan toleransi. Hal ini dikarenakan ketika seseorang bercermin kepada kehidupan Rasulullah saw. Maka di sana, dia akan menemukan jalinan benang perdamaian dan toleransi. Perdamaian adalah hal yang fundamental dalam Islam. Ada banyak ayat dalam alQur'an dan sîrah nabawiyyah yang menjelaskan tentang hal ini, QS. alAnfal: 61:

Dan jika mereka condong kepada perdamaian, maka condonglah kepadanya dan bertawakallah kepada Allah. Sesungguhnya Dialah Yang Maha Mendengar lagi Maha Mengetahui. ${ }^{40}$

Bahkan dalam suasana ketika dua pasukan telah berjuang melawan satu sama lain dan darah telah tumpah, jika musuh tidak jadi bertempur dan ingin membuat perjanjian, maka orang-orang muslim diperintahkan untuk tidak bereaksi secara emosional, tetapi membuat perjanjian, dan percaya kepada Allah. Dengan demikian, prinsip universal mengenai permasalahan ini sudah ada. Jadi, pertempuran atau konflik benar-benar bertentangan dengan semangat dasar agama yang memerintahkan perjanjian dan rekonsiliasi, tidak hanya dalam masa damai, tetapi bahkan selama masa perang. ${ }^{41}$

Misi Nabi saw adalah untuk mengkomunikasikan iman seperti yang telah diperintahkan oleh Allah swt. Beliau melakukan ini tanpa prasangka apapun. Nabi saw, sosok yang penuh cinta dan damai ini, bahkan mengunjungi orang-orang kafir yang paling keras hati, seperti $\mathrm{Abu}$

\footnotetext{
${ }^{38}$ Muhammad ibn 'Isâ al-Tirmidziy, al-Jâmi' al-Kabîr li al-Tirmidziy, Vol. 3, 276-277.

${ }^{39}$ M. Fethullah Gulen, Toward a Global Civilization, 174.

${ }^{40}$ Tim Penyusun, al-Qur'an dan Terjemahnya, 271.

${ }^{41}$ Ibid., 176.
} 
Jahal dan 'Uqbah bin Abi Mu'ayd, berkali-kali tanpa menunjukkan kebencian apapun. Beliau menginginkan semua orang bisa merasakan surga di dalam hati mereka. Beliau sering bersabda:

"Katakan tidak ada Tuhan selain Allah dan selamatlah."

Menurut Fethullah Gulen, apa yang dimaksud dengan hadis ini adalah: "Untuk meraih keinginan dalam hatimu, bantulah benih keyakinan yang telah ditaburkan dalam hatimu untuk tumbuh ke dalam surga dan selamatkan duniamu yang lain." Ketika itu Abu Jahal menjawab seruan ini dengan cara yang tidak sopan dan mengejek, "Hai Muhammad, jika kamu melakukan ini agar kami menjadi saksi di hadapan Tuhan, jangan mengajak aku lagi untuk mengikuti agamamu. Aku akan bersaksi di sana”. Orang kafir ini selalu menjawab tanpa hormat. Tapi meskipun Abu Jahal menghina, Rasulullah saw, sosok yang paling mulia di dunia itu, tetap berbicara tentang Islam setiap kali mereka bertemu dan tidak pernah mengubah gaya beliau; kata-kata, sikap, dan penghinaaan tidak pernah mempengaruhi dirinya. ${ }^{43}$

Contoh lainnya yang berkaitan dengan peristiwa yang berhubungan dengan cinta, belas kasih, dan toleransi Rasulullah saw kepada umat manusia, terjadi selama penaklukan kota Mekah. Setelah penaklukan itu selesai, semua orang berkumpul di sekitar Nabi saw dan, menatap mata beliau, mereka mulai menunggu beliau membuat keputusan mengenai nasib mereka. Sampai di saat-saat terakhir sebuah kelompok kecil, di antaranya adalah anak Abu Jahal, Ikrimah, telah menghadang orang-orang muslim untuk memasuki Mekah. Sekali lagi rasa kekerasan dan dendam mereka meradang. Pada saat suasana begitu tegang, Rasulullah saw bertanya kepada orang-orang Mekah yang menunggu dengan antisipasi dan kecemasan, "Apa yang dapat aku lakukan untuk kalian?" Beberapa orang Mekah yang tahu benar betapa mulia, pemaaf, dan murah hatinya beliau, tidak kuasa menahan diri dan menunjukkan perasaan dan berkata, "Engkau adalah orang yang paling murah hati dan paling mulia." Tujuan Nabi saw bukanlah harta maupun kekayaan, bukan juga kedaulatan atau kekuasaan, bukan juga penaklukan, tujuan beliau adalah untuk menyelamatkan orang-orang dan

42 Redaksi lain berbunyi قل لا إله إلا الله كلمة أحاج للك بها عند الله Ismâ'̂́l ibn Kathîr, al-Bidâyah wa alNihâyah, Vol. 3, (Beirut: Dâr lhyầ' al-'Arabiy, 1988), 153; Muhammad ibn Ismâ'îl al-Bukhâriy, al-Jâmi' al-Sahîh, Vol. 12, 268.

${ }^{43}$ Ibid., 176-177. 
menaklukkan hati mereka. Manusia yang penuh cinta dan kasih sayang ini memberikan keputusan tentang musuh-musuh, dengan mengatakan:

Aku berkata kepada kalian seperti Yusuf pernah berkata kepada saudarasaudaranya. Tidak ada kesalahan atas tindakan yang telah kalian lakukan sebelumnya. Allah akan mengampuni kalian juga. Dia lah Yang Maha Pengasih lagi Maha Penyayang. Pergilah, kalian semua bebas. ${ }^{44}$

Menurut Fethullah Gulen, apa yang sebenarnya dimaksud dalam pendekatan ini dapat dinyatakan sebagai berikut: "Janganlah memendam rasa sakit dalam batin. Aku tidak bermaksud untuk menghukum siapa pun. Perilaku setiap orang menampilkan karakternya. Beginilah aku melakukan sesuatu". 45

Setelah kembali ke Madinah, Ikrimah ibn Abu Jahal, yang telah menumpahkan darah bahkan selama penaklukan Mekah, diyakinkan oleh istrinya, Ummu Hakim untuk kembali dari tempat pelariannya, dan menghadap Rasulullah saw. Sebelum dia bertemu Nabi saw, orang-orang di sekitarnya mengatakan bahwa jika ia meminta maaf, Rasulullah akan memaafkannya. Dengan semua kemungkinan, sebelum Ikrimah datang menemui Nabi saw, beliau telah memperingatkan orang-orang di sekelilingnya, "Ikrimah akan datang. Jangan melukai perasaannya dengan mengatakan hal-hal yang tidak pantas tentang ayahnya." Begitu Ikrimah melangkah masuk, Rasulullah saw berkata dengan lembut, "Selamat datang orang yang berhijrah dengan perahu". Tanpa mengharapkan katakata penuh kasih sayang, Ikrimah kemudian berkata, "Selama aku hidup, aku tidak akan pernah melupakan perilaku Nabi." Empat tahun setelah Ikrimah menjadi seorang Muslim, ia menjadi syahid dalam pertempuran di Yarmuk. Setelah menggumamkan kata-kata: "Wahai Rasulullah, sudahkan engkau menemukan kebaikan yang engkau harapkan sebagai kompensasi atas kejahatan yang dilakukan oleh orang yang berhijrah dengan perahu?" ia bergabung dengan syuhada lainnya. ${ }^{46}$

Seperti yang disebutkan di depan, seruan Rasulullah saw adalah misi beliau untuk merepresentasikan kebenaran yang beliau sampaikan kepada orang lain. Dengan kata lain, itu adalah tugas beliau untuk menjalankan dalam hidup beliau apa yang beliau katakan. Beliau selalu mempraktikkan sesuatu sebelum meminta orang lain untuk melakukan

\footnotetext{
${ }^{44}$ Ibid., 176.

${ }^{45}$ Ibid., 177.

${ }^{46}$ Ibid., 177-178.
} 
hal yang sama. Hal-hal yang telah kami jelaskan sejauh ini mencakup karakter umum Rasulullah saw. Namun, beberapa orang mencoba sebisa mungkin untuk menafsirkan secara salah mengenai keberadaan dan dorongan untuk jihad dalam al-Qur'an dan Sunnah sehingga tampaknya bertentangan dengan cinta dan kasih sayang Nabi kita yang universal. Jihad memang dapat berarti perjuangan bersenjata dengan kondisi khusus yang kadang-kadang perlu dilakukan dalam rangka melindungi nilai-nilai seperti kehidupan, harta, agama, anak, tanah air, dan kehormatan. Perjuangan bersenjata juga kadang-kadang terpaksa harus dilakukan untuk menyingkirkan hambatan yang menghalangi jalan untuk menegakkan kalimat Allah. Hari ini dua situasi ini terus membingungkan, kadang-kadang karena ketidaktahuan dan kadang-kadang dilakukan dengan sengaja. Cinta, kasih sayang, dan toleransi, dalam dimensi yang luas, sangat terasa selama masa Rasulullah saw, zaman yang penuh kedamaian dan kebahagiaan, zaman yang dalam kata-kata Nabi saw disebut, "Era Terbaik". Bahkan, periode ini merupakan puncak peradaban Islam; era keemasan ketika damai, cinta, dan pengertian diberi posisi yang benar di masyarakat. ${ }^{47}$

\section{Jihad dan HAM Menurut Muhammad Fethullah Gulen}

Menurut Muhammad Fethullah Gulen, Islam sangat menghargai Hak Asasi Manusia. Dalam ajaran Islam, tidak dibenarkan bahwa seseorang menghilangkan nyawa orang lain secara tidak adil, bahkan ditegaskan bahwa barangsiapa yang membunuh satu orang dengan tidak adil, maka dosanya sama dengan membunuh seluruh manusia. Dalam hal ini, dia menyatakan:

Islam adalah agama yang seimbang, luas, dan universal dalam urusan hak asasi manusia. Namun ada orang-orang yang berusaha untuk meruntuhkan negara atau pemerintahan yang sah, atau yang telah tega merenggut hidup seseorang. Mengajarkan umat Islam bahwa mengambil nyawa seseorang secara tidak adil adalah kejahatan terhadap seluruh umat manusia. Ajaran seperti ini tidak dapat ditemukan pada agama atau sistem modern manapun, dan nilai luhur seperti ini tidak pernah dilekatkan pada kehidupan manusia oleh komisi atau organisasi hak asasi manusia manapun. Dalam Islam, membunuh satu orang dianggap seolah-olah membunuh seluruh umat manusia, karena mentolerir pembunuhan

${ }^{47}$ Ibid., 178. 
terhadap satu orang dapat memicu gagasan bahwa setiap orang dapat dibunuh. ${ }^{48}$

Untuk mendukung argumen di depan, Fethullah Gulen mengutip sebuah kisah yang diterangkan dalam QS. al-Maidah: 27-28 dan 32, serta al-Nisa' 93:

Ceritakanlah kepada mereka kisah kedua putera Adam (Habil dan Qabil) menurut yang sebenarnya, ketika keduanya mempersembahkan korban, maka diterima dari salah seorang dari mereka berdua (Habil) dan tidak diterima dari yang lain (Qabil). Ia berkata (Qabil): "Aku pasti membunuhmu!" Berkata Habil: "Sesungguhnya Allah hanya menerima (korban) dari orang-orang yang bertakwa". "Sungguh kalau kamu menggerakkan tanganmu kepadaku untuk membunuhku, aku sekali-kali tidak akan menggerakkan tanganku kepadamu untuk membunuhmu. Sesungguhnya aku takut kepada Allah, Tuhan seru sekalian alam." ${ }^{49}$

Menurut Fethullah Gulen, ayat di depan berisi sebuah kisah yang menceritakan pembunuhan pertama dalam sejarah manusia. Putra Nabi Adam as, Qabil, adalah manusia pertama yang menumpahkan darah. Meskipun namanya tidak disebutkan secara eksplisit dalam al-Qur'an atau Sunnah, dapat diketahui dari kitab-kitab sebelumnya bahwa antara dua bersaudara, Qabil dan Habil, telah terjadi kesalahpahaman, dan Qabil telah membunuh Habil secara tidak adil karena cemburu, sehingga membuka sebuah era pertumpahan darah. Untuk alasan ini, dalam salah satu hadis riwayat al-Bukhari dari 'Abd Allah ibn 'Abbas, Rasulullah saw bersabda:

Tidak ada satu jiwa pun yang dibunuh karena kezaliman kecuali putra Adam yang pertama (yang membunuh) akan menanggung sebagian dari dosa pembunuhannya karena dialah orang pertama yang melakukan pembunuhan..$^{50}$

Dalam kaitannya dengan pembunuhan, dalam QS. al-Maidah: 32 juga dinyatakan:

Barang siapa yang membunuh seorang manusia, bukan karena orang itu (membunuh) orang lain, atau bukan karena membuat kerusakan di muka bumi, maka seakan-akan dia telah membunuh manusia seluruhnya. Dan barang siapa yang memelihara kehidupan seorang

\footnotetext{
48 lbid., 169.

${ }^{49}$ Tim Penyusun, al-Qur'an dan Terjemahnya, 163.

${ }^{50}$ Muhammad ibn Ismâ'îl al-Bukhâriy, al-Jâmi' al-Shahîh, Vol. 21, 156.
} 
manusia, maka seolah-olah dia telah memelihara kehidupan manusia semuanya. ${ }^{51}$

Prinsip ini bersifat universal dan karena itu berlaku sepanjang zaman. Bahkan dalam QS. al-Nisa' 93 ditegaskan:

Dan barang siapa yang membunuh seorang mukmin dengan sengaja, maka balasannya ialah Jahanam, kekal ia di dalamnya dan Allah murka kepadanya, dan mengutukinya serta menyediakan azab yang besar baginya. $^{52}$

Selain tiga ayat yang dikutip Fethullah Gulen di atas, dia juga mengutip beberapa hadis Nabi saw yang berisi perlindungan Islam terhadap hak memiliki harta, hak hidup, hak beragama, dan hak bereproduksi, yakni:

'Abd bin Humaid bercerita kepada kami, dia berkata: Ya'qub ibn Ibrahim ibn Sa'd bercerita kepadaku: Ayahku bercerita kepada kami dari ayahnya dari Abu 'Ubaidah ibn Muhammad ibn 'Ammar ibn Yasir dari Talhah ibn 'Abd Allah ibn 'Auf dari Sa'id ibn Zaid, dia berkata: Saya mendengar Rasulullah saw bersabda: "Orang yang terbunuh karena mempertahankan hartanya adalah syahid. Orang yang terbunuh karena mempertahankan agamanya adalah syahid. Orang yang terbunuh karena mempertahankan darah (nyawa)nya adalah syahid. Orang yang terbunuh karena mempertahankan keluarganya adalah syahid. ${ }^{53}$

Menurut Fethullah Gulen, semua nilai-nilai yang disebutkan dalam hadis ini digunakan sebagai prinsip-prinsip yang terpisah dalam semua sistem hukum. Dari sinilah kebebasan beragama, kehidupan, reproduksi, kesehatan mental, dan hak milik pribadi menjadi hal-hal mendasar yang penting yang harus dipertahankan oleh semua orang. Islam memandang hak asasi manusia dari sudut prinsip-prinsip yang mendasar ini. ${ }^{54}$

Menurut Fethullah Gulen, hanya Islam yang menghormati umat manusia dengan gelar "khalifah Allah". Tidak ada sistem atau agama lain melakukan hal ini. Selain itu, Islam menyatakan bahwa segala sesuatu yang ada di langit dan bumi tunduk kepada hukum Allah, untuk kepentingan umat manusia asalkan digunakan dengan cara yang benar. Dan Islam juga sangat menghormati dan menjunjung tinggi Hak Asasi Manusia. Maka

\footnotetext{
${ }^{51}$ Tim Penyusun, al-Qur'an dan Terjemahnya, 164.

52 lbid. 136.

${ }^{53}$ Muhammad ibn 'Isâ al-Tirmidziy, al-Jâmi' al-Kabîr li al-Tirmidziy, Vol. 3, 88-89.

${ }^{54}$ M. Fethullah Gulen, Toward a Global Civilization, 170.
} 
tidak dibenarkan jika seseorang melakukan berbagai macam perusakan dengan mengatasnamakan Islam. ${ }^{55}$

\section{Jihad dan Terorisme Menurut Muhammad Fethullah Gulen}

Menurut Muhammad Fethullah Gulen, Islam secara harfiah berarti "berserah diri", sehingga Islam dapat diartikan sebagai agama kepuasan, keamanan, dan perdamaian. Prinsip-prinsip ini melekat dalam kehidupan umat Islam yang dicerminkan dalam ritual shalat mereka. Ketika kaum muslimin memulai shalat, mereka memutuskan semua hubungan dengan dunia, membungkuk dan sujud di hadapan Allah dan kemudian berdiri dengan tangan bersedekap dengan penuh khusyuk. Mereka mengakhiri shalat dengan ucapan salam kepada mereka yang di kiri dan kanan dan berharap agar mereka selalu sehat, aman dan damai, kemudian pergi dan bergabung dengan orang lain. ${ }^{56}$

Memberi salam kepada orang lain dan mengharapkan perdamaian untuk mereka dianggap salah satu tindakan yang paling terpuji dalam Islam. Hal ini disandarkan kepada salah satu sabda Nabi saw:

Qutaibah bercerita kepada kami: Dia berkata: al-Laith bercerita kepada kami dari Yazid ibn Abu Hubaib dari Abu al-Khair dari 'Abd Allah ibn 'Amr: Sesungguhnya ada seorang lelaki yang bertanya kepada Rasulullah saw: "Perbuatan apa yang paling disukai dalam Islam?" Beliau lalu menjawab, "Memberi makanan untuk orang lain dan ucapan salam kepada semua orang yang kalian kenal dan yang tidak kalian kenal."${ }^{.57}$

Fethullah Gulen menolak pandangan sebagian orang yang menghubungkan terorisme dengan Islam. Padahal hal tersebut dilakukan oleh sebagian kecil umat Islam yang salah kaprah memahami ajaran Islam. Dalam ini, Fethullah Gulen menyatakan:

Sangat memalukan jika Islam yang didasarkan pada prinsip tersebut dipandang orang lain setara dengan terorisme. Ini adalah kesalahan besar dari sejarah. Jika sistem yang didasarkan pada perdamaian dan keamanan dihubungkan dengan terorisme, ini hanya menunjukkan bahwa orangorang yang membuat tuduhan itu tidak tahu apa-apa tentang semangat Islam dan tidak dapat memahaminya. Seseorang harus mempelajari Islam melalui sumber-sumber dan representasi yang benar sepanjang sejarah;

\footnotetext{
${ }^{55} \mathrm{lbid}$.

${ }^{56} \mathrm{lbid} ., 179$.

${ }^{57}$ Ahmad ibn Syu'aib al-Nasâ'iy, Sunan al-Nasâ'iy, Vol. 6, (Beirut: Dâr al-Kutub al-'Ilmiyyah, 1991), 531.
} 
bukan melalui tindakan-tindakan minoritas yang salah kaprah merepresentasikan Islam. ${ }^{58}$

Dalam pandangan Fethullah Gulen, tidak ada kekerasan atau fanatisme buta dalam Islam. Islam adalah agama yang dirancang sepenuhnya berdasarkan ampunan dan toleransi. Hal ini seperti yang sampaikan oleh para tokoh Islam seperti Rumi, Yunus Emre, Ahmed Yesevi, Badiuzzaman dan lainnya. Mereka dicatat dalam sejarah sebagai contoh-contoh dari kasih sayang dan toleransi. ${ }^{59}$

Fethullah Gulen menolak pandangan sebagian orang yang salah mengartikan Jihad dalam Islam. Di dalam Islam, jihad merupakan sebuah sarana dan proses manusia menuju Allah yang bersifat batiniah, sekaligus usaha riil untuk menghalau semua hambatan yang mengganggu pertahanan dan penegakan kalimat Allah yang meniscayakan adanya peperangan seperti yang tercatat dalam sejarah. Tetapi sangat disayangkan, ketika ayat-ayat dalam al-Qur'an yang menetapkan persyaratan untuk jihad telah disalah-artikan oleh orang-orang lain dan dianggap sebagai tujuan fundamental Islam. Orang-orang yang berpandangan keliru tentang Islam ini sebenarnya telah gagal memahami semangat Islam secara komprehensif, apalagi hati mereka telah dirasuki kebencian, sehingga mereka menjadi salah dalam menafsirkan Islam. Padahal hati umat Islam yang sejati penuh cinta dan kasih sayang kepada semua makhluk. ${ }^{60}$

Menurut Fethullah Gulen, membunuh manusia adalah tindakan yang sama gawatnya dengan kufur (tidak percaya kepada Allah). Tidak seorang pun berhak membunuh manusia. Tidak seorang pun berhak mengusik orang yang tidak bersalah, bahkan pada saat perang. Tidak seorang pun bisa memberikan fatwa (sebuah keputusan hukum dalam Islam, yang dikeluarkan oleh para ulama mengenai isu tertentu) dalam hal ini. Tidak seorang pun dapat dibenarkan untuk meledakkan bom bunuh diri. Tidak seorang pun diperbolehkan menyeruak ke dalam kerumunan orang banyak dengan bom melilit di tubuhnya. Terlepas dari apa agama yang dianut oleh kerumunan itu, tindakan itu tidak diperbolehkan agama. Bahkan dalam keadaan perang -saat yang sulit untuk mempertahankan keseimbangan- hal ini tetap tidak diperbolehkan dalam Islam. Islam menyatakan, "Jangan sentuh anak-anak atau orang-orang yang sedang

\footnotetext{
${ }^{58} \mathrm{M}$. Fethullah Gulen, Toward a Global Civilization, 179.

${ }^{59} \mathrm{lbid}$.

${ }^{60} \mathrm{lbid}$.
} 
beribadah di gereja”. Ini tidak hanya dikatakan sekali, tetapi telah berulang-ulang sepanjang sejarah. Apa yang disabdakan junjungan kita, Nabi Muhammad saw, apa yang dikatakan Abu Bakar, dan apa yang disampaikan 'Umar bin Khattab sama dengan apa yang kemudian juga diserukan Salahuddin al-Ayyubi, Alparslan, dan Kılıçarslan. Setelah itu, Sultan Mehmet II, Sang Penakluk, juga mengatakan hal yang sama.

Dengan demikian, kota Konstantinopel, yang pernah kacau balau, telah menjadi Istanbul. Di kota ini, orang-orang Yunani tidak mengganggu orang-orang Armenia, demikian juga orang-orang Armenia tidak mengganggu orang-orang Yunani. Tidak juga umat Islam mengganggu umat agama lain. Tidak lama setelah penaklukan Konstantinopel, penduduk kota itu menggantung potret besar Sang Penakluk pada dinding di tempat kediaman Keuskupan. Sangat menakjubkan bahwa perilaku seperti itu muncul pada waktu itu. Kemudian, sejarah mencatat bahwa Sultan memanggil Uskup dan memberinya kunci untuk memasuki kota itu. Hingga saat ini, keuskupan mengenangnya dengan rasa hormat. ${ }^{61}$

Solusi yang ditawarkan Muhammad Fethullah Gulen untuk menangkal terorisme adalah melalui spiritualitas dan pendidikan. Dalam hal ini, dia menyatakan:

Orang dapat dilindungi dari terlibat dalam terorisme melalui beberapa kebajikan yang berasal dari keimanan dalam Islam, seperti, takut akan Allah, takut akan hari kiamat, dan takut menentang prinsip-prinsip agama. ${ }^{62}$

Dalam hal pendidikan, Fethullah Gulen mengkritisi sistem pendidikan, khususnya yang berada di Turki, yang menghapus pendidikan moral dan budaya di dalamnya. Sehingga hal ini memicu berbagai macam kejahatan di dalam masyarakat seperti penyalahgunaan narkoba, perjudian, dan korupsi. Dalam hal ini, dia menyatakan:

Orang-orang ini tumbuh di antara kita. Mereka adalah anak-anak kita. Mengapa sebagian dari mereka menjadi orang-orang jahat? Mengapa beberapa diantara mereka menjadi pengganggu? Mengapa beberapa dari mereka memberontak terhadap nilai-nilai kemanusiaan? Mengapa mereka datang ke negara mereka sendiri dan meledakkan diri sebagai pembom bunuh diri? Orang-orang ini dibesarkan di antara kita. Oleh karena itu,

\footnotetext{
${ }^{61} \mathrm{lbid}$.

${ }^{62}$ Ibid., 188.
} 
pasti ada sesuatu yang salah dengan pendidikan mereka. Artinya, sistemnya pasti memiliki beberapa kekurangan dan titik lemah yang perlu diperiksa. Titik-titik lemah ini perlu dihapus. Singkatnya, pengembangan manusia tidak diberi prioritas. Sementara itu, beberapa generasi telah hilang, hancur, dan sia-sia. ${ }^{63}$

Menurut Fethullah Gulen, sistem pendidikan yang salah akan melahirkan manusia-manusia yang labil karena kering dari spiritualitas, sehingga mereka akan mudah digunakan sebagai "robot" oleh orang-orang tertentu demi memuluskan tujuannya. Mereka telah digunakan sebagai pembunuh dengan dalih beberapa cita-cita atau tujuan gila. Hal ini seperti yang terjadi dalam berbagai kejadian berdarah di Turki pada 12 Maret 1971 dan 12 September 1980 di mana orang-orang keluar rumah untuk saling membunuh. Dalam hal ini, dia menyatakan:

Beberapa orang berusaha untuk mencapai tujuan dengan membunuh orang lain. Semua orang menjadi teroris. Orang-orang di sebelah sana teroris, orang-orang di sebelah sini teroris juga. Tapi, setiap orang memberi label yang berbeda-beda terhadap tindakan yang sama. Seseorang berkata, "Aku melakukan ini atas nama Islam”. Orang lain berkata, "Aku melakukannya demi bangsa dan tanah airku”. Yang lainnya lagi, "Aku berperang melawan kapitalisme dan eksploitasi”. Ini semua hanya katakata. Al-Qur'an menyebut "label-label" ini sebagai hal-hal yang tak bernilai. Tetapi orang-orang terus saja membunuh. Setiap orang membunuh atas nama cita-cita. ${ }^{64}$

Menurut Fethullah Gulen, situasi ini semestinya dulu dapat dicegah melalui pendidikan dengan memberikan pemahaman secara jelas bahwa umat Islam tidak boleh menjadi teroris. Karena jika mereka melakukan tindak kejahatan, meskipun sekecil atom, mereka harus mempertanggungjawabkannya, baik di dunia sini maupun di akhirat kelak. Sekali lagi, menurut Fethullah Gulen, membunuh manusia adalah hal yang sangat besar. Al-Qur'an mengatakan bahwa membunuh satu orang sama dengan membunuh semua orang. Dengan mengutip pendapat ibn 'Abbas ra., Fethullah Gulen mengatakan bahwa pembunuh akan tinggal di neraka untuk selamanya. Ini adalah hukuman yang sama yang diberikan kepada orang-orang kafir. Ini berarti bahwa seorang pembunuh terkena hukuman yang sama seperti seorang yang tidak beriman. Singkatnya, dalam Islam, dalam hal hukuman yang akan ditimpakan pada

${ }^{63}$ Ibid., 189.

64 Ibid. 
hari kiamat, seorang pembunuh akan dianggap serendah seseorang yang menolak Allah dan Nabi (dengan kata lain seorang atheis). Jika ini adalah prinsip agama yang mendasar, maka ini harus dimasukkan dalam kurikulum pendidikan. ${ }^{65}$

\section{Analisis terhadap Jihad dalam Perspektif Muhammad Fethullah Gulen}

Pemikiran seorang manusia tidak dapat dilepaskan dari berbagai latar belakang yang melingkupinya, seperti pengalaman pribadi, pendidikan, kondisi politik-sosial dan lainnya, termasuk Muhammad Fethullah Gulen. Seperti yang dinyatakan dalam biografi di depan, bahwa Fethullah Gulen dilahirkan dan dibesarkan dalam lingkungan keluarga yang religius, penuh cinta dan kasih sayang. Hal ini berpengaruh pada kepribadian dan pemikiran Fethullah Gulen yang cenderung kepada penolakan terhadap segala bentuk kekerasan yang mengatasnamakan agama.

Menurut Gülen, Islam bukanlah sumber masalah, tapi Islam merupakan ajaran yang berisi tentang perintah kasih sayang dan toleran kepada semua. Karena itu, ia berusaha menemukan benang kusut pertemuan Islam dengan modernitas, dan perpaduan Islam dengan nilainilai humanisme universal yang dianut di Barat. Persoalan bagaimana Islam bisa hidup di alam modern yang sadar akan kemajemukan inilah yang kemudian melatari Fethullah Gülen merajut pemikiran pemikirannya dalam buku Toward a Global Civilization of Love Tolerance. ${ }^{66}$

Dalam pemikiran M. Fethullah Gulen, sufisme merupakan spirit mendasar yang menjadi landasan semua konsep pemikirannya. Konsep ini merupakan ekspresi dari usaha pencerahan yang dilakukan oleh Gulen, sedangkan dakwah merupakan konsekuensi wujud langsung dari pencerahan ini. Bentuk dakwah ini adalah hizmet yang mengutamakan keteladanan (uswah). Pemikiran dakwah sufistik Gülen ini dapat ditelusuri sumbernya dari buku-buku yang ia tulis: Criteria or the Light of

\footnotetext{
${ }^{65}$ Ibid., 190.

${ }^{66}$ HM Syamsudini, "Cinta dan Toleransi Perspektif Fethullah Gulen", Edu Islamika, Volume 05, Nomor 02, September 2013, 379.
} 
the Way, Pearls of Wisdom, Toward a Global Civilization of Love and Tolerance, The Necessity of Interfaith Dialogue: A Muslim Perspective. ${ }^{67}$

Penguasaan Fethullah Gulen terhadap khazanah spiritual, ilmuilmu agama keislaman, dan filsafat barat menjadikannya seorang pemikir modernis radikal. Seorang modernis radikal akan mencoba untuk menginterpretasikan ajaran Islam dengan pendekatan yang rasional dan menyesuaikannya dengan perkembangan dunia modern secara radikal. Dia akan berusaha mendialektikakan dan mengharmonisasikan antara agama dan modernisasi di dunia Islam. Dia memiliki sikap yang terbuka terhadap berbagai sistem, metode, atau khazanah yang berasal dari peradaban lain sepanjang hal tersebut akan mampu memberikan manfaat bagi kehidupan. ${ }^{68} \mathrm{Hal}$ ini terlihat dari pemaparan Fethullah Gulen terhadap makna jihad dalam Islam yang menekankan pada harmonisasi antara jihad besar yang bersifat batiniah dan jihad kecil yang bersifat lahiriah, serta penerimaannya terhadap konsep Hak Asasi Manusia yang berasal dari Barat.

Berdasarkan pemikiran Gulen, diketahui bahwa konsep jihad Gulen didasarkan pada episteme irfani. Episteme irfani menitikberatkan pada penafsiran aspek esoteric agama. Esoterisme ditekankan oleh kaum sufi ketika mereka menyadari bahwa kaum muslim telah menghabiskan banyak energy dalam perang bersenjata melawan tentara musuh di kawasan ekspansi, tetapi tampaknya kaum muslim mulai mengabaikan perang melawan diri sendiri yang terkotori oleh nafsu.

Melihat kenyataan itu, kaum sufi kembali mengingatkan betapa pentingnya perang spiritual melawan diri sendiri. Maka mereka mengartikan jihad sebagai bentuk perjuangan melawan kotoran hati. Meskipun demikian, jihad dengan kekerasan dan mengangkat senjata tetap dibutuhkan untuk membela diri dari agresi musuh. Bahkan, mereka tidak menafikan tingginya derajat berjihad dengan harta dan jiwa. ${ }^{69}$

\section{Simpulan}

Dari pembahasan di depan dapat disimpulkan bahwa Muhammad Fethullah Gulen adalah seorang pemikir modern muslim. Dia dilahirkan

\footnotetext{
${ }^{67}$ Sokhi Huda, "Pemikiran dan Praksis Dakwah Sufistik M. Fethullah Gülen, 313.

${ }^{68}$ Muhammad Chirzin, "Jihad dalam al-Qur'an Perspektif Modernis dan Fundamentalis" dalam Hermeneia, Vol. 2 No. 1 (Januari-Juni 2003), 97.

${ }^{69}$ Irwan Masduqi, Ketika Non Muslim Membaca al-Qur'an, 78.
} 
dan tumbuh di sebuah lingkungan yang religius dan dalam kondisi sosialpolitik yang mencari bentuk pasca keruntuhan Khilâfah Uthmâniyyah. Jihad dalam pandangan Fethullah Gulen dipandang bukan sebagai tujuan, melainkan sebuah proses dalam kehidupan seorang muslim agar lebih dekat dan mengenal Allah. Jihad dibagi menjadi dua, yakni jihad besar yang bersifat spiritual dan jihad kecil yang bersifat fisik. Dan kedua jihad ini harus berjalan beriringan agar terjadi harmoni dalam diri seorang muslim. Fethullah Gulen menolak semua bentuk kekerasan yang mengatasnamakan Islam, khususnya terorisme. Karena pada dasarnya, Islam adalah agama perdamaian dan perlindungan.

\section{Daftar Rujukan}

Al-Bukhâriy, Muhammad ibn Ismầîl. al-Jâmi' al-Shahîh li al-Bukhâriy. Beirut: Dâr al-Fikr, tt.

Chirzin, Muhammad. "Jihad dalam al-Qur'an Perspektif Modernis dan Fundamentalis" dalam Hermeneia, Vol. 2 No. 1 (Januari-Juni 2003).

Gulen, Muhammad Fethullah. "Siapakah Fethullah Gulen?" dalam www.fgulen.com, diakses 30 Desember 2016.

"Edirne, Kirklareli, dan Akhirnya Izmir" dalam www.fgulen.comdiakses 30 Desember 2016.

, "Fethullah Hodjaefendi" dalam www.fgulen.com diakses 30 Desember 2016.

, "Pendidikan Dasar dan Kepribadian M. Fethullah Gulen" dalam www.fgulen.com diakses 30 Desember 2016.

"Wajib Militer" dalam www.fgulen.com diakses 30 Desember 2016.

, Toward a Global Civilization of Love and Tolerance. New Jersey: The Light Inc. 2004.

Al-Hajjầ, Muslim ibn., al-Jâmi' al-Shahîh li Muslim. Beirut: Dâr al-Fikr, tt.

Huda, Sokhi. "Pemikiran dan Praksis Dakwah Sufistik M. Fethullah Gülen". Islamica. Volume 11, Nomor 2, Maret 2017.

Kathîr, Ismâ'îl ibn 'Umar ibn. Tafsîr al-Qur'ân al-'Adîm. Madinah: Dâr Thaibah li al-Nashr wa al-Tauzî̀, 1999.

1988. ,al-Bidâyah wa al-Nihâyah. Beirut: Dâr Ihyâ' al-'Arabiy, 
Ma'afi, Rif at Husnul. dan Muttaqin "Konsep Jihad dalam Perspektif Islam", Kalimah, Volume 11, Nomor 1, Maret 2013.

Masduqi, Irwan. Ketika Non Muslim Membaca al-Qur'an. Yogyakarta: Bunyan, 2013.

Al-Nasâiy, Ahmad ibn Shu'aib. Sunan al-Nasâ’iy. Beirut: Dâr al-Kutub al-'Ilmiyah, 1991.

Syamsudini, HM. "Cinta dan Toleransi Perspektif Fethullah Gulen”, Edu Islamika, Volume 05, Nomor 02, September 2013.

Tim Penyusun. al-Qur'an dan Terjemahnya, Madinah: Mujamma' alMâlik Fahd li Thibâ'ah al-Mushhaf al-Syarîf, $1418 \mathrm{H}$.

Al-Tirmidziy, Muhammad ibn 'Isâ. al-Jâmi' al-Kabîr li al-Tirmidziy. Beirut: Dâr al-Gharb al-Islâmiy, 1996. 